Article

\title{
Mediatizing Slum Relocation in Egypt: Between Legitimization and Stigmatization
}

\author{
Hassan Elmouelhi ${ }^{1, *}$, Martin Meyer ${ }^{1}$, Reham Reda ${ }^{2}$ and Asmaa Abdelhalim ${ }^{2}$ \\ ${ }^{1}$ Department of Urban Development, Technische Universität Berlin, Germany; E-Mails: elmouelhi@tu-berlin.de (H.E.), \\ m.meyer@tu-berlin.de (M.M.) \\ 2 Department of Urban Development, Technische Universität Berlin - El Gouna, Egypt; \\ E-Mails: r_reda@aucegypt.edu (R.R.), asmaa.abdelrazzak@gmail.com (A.A) \\ * Corresponding author
}

Submitted: 7 May 2021 | Accepted: 15 November 2021 | Published: 17 December 2021

\begin{abstract}
In Egypt, the relocation of residents of informal areas of housing into "proper" living environments is presented as a major political achievement offering citizens a much-improved quality of life. Therefore, it is not surprising that, following the Arab Uprisings, the current regime is widely publicizing relocation projects as success stories on TV and social media. As a way of garnering legitimization and securing stability, this official representation is reshaping the residents' urban life and evoking narratives of slum dwellers' transformation into respected citizens. Tackling a new area of interdisciplinary research between urban studies and media and communication studies, this article investigates the portrayal in mainstream media channels and social media platforms of two relocation projects (Al-Asmarat in Cairo and Al-Max in Alexandria), contrasting them with the residents' perceptions of their new homes and their efforts to produce counter-imagery. The authors argue that both the state-dominated representation of the Al-Asmarat resettlement as an ideal solution to the crisis of informal settlements, as well as the more bottom-up construction of the Al-Max community as a picturesque fishing community, do not reflect the material experience of the inhabitants-despite it being presented as such in nationwide reporting. The effective centering of the public debate around the mediatized images has thus deflected criticism and enabled urban development projects to be positioned to legitimize the current rule despite the shortcomings of their implementation.
\end{abstract}

\section{Keywords}

informal settlements; legitimization; mediatization; relocation; social media; urban development

\section{Issue}

This article is part of the issue "Ten Years after the Arab Uprisings: Beyond Media and Liberation," edited by Hanan Badr (Gulf University for Science and Technology, Kuwait) and Lena-Maria Möller (Max Planck Institute for Comparative and International Private Law, Germany).

(C) 2021 by the authors; licensee Cogitatio (Lisbon, Portugal). This article is licensed under a Creative Commons Attribution 4.0 International License (CC BY).

\section{Introduction}

Egypt has a long-standing tradition of instrumentalizing urban development and housing projects to garner political support and demonstrate the government's capacity to improve the citizen's livelihoods-which in turn legitimizes the regime. Prominent examples are Downtown Cairo, a prestige project by Khedive Ismail (Abu-Lughod, 2018; Sims \& Abu-Lughod, 2010) and the various generations of new towns such as 10th of Ramadan and 6th of October under Sadat, New Cairo, Sherouk, and Badr under Mubarak, the New Administrative Capital and the fourth generation of new towns under El-Sisi's administration (Elmouelhi, 2019; Sims \& Abu-Lughod, 2010). While these examples mainly target the middle classes and have been propagated as such, they are linked to the question of informal settlements, the right to decent housing, and social justice, which have been key issues of the 2011 uprisings. Slum clearance has been widely discussed in Egyptian media, often with a strong 
bias against informal areas and the patronizing figure of the "slum-dweller." In 2018, President El-Sisi declared to free Egypt from "ashwa'eyat" by the end of the following year (Karima, 2018). The term ashwa'eyat, meaning haphazard or spontaneous, is widely used in Egypt and Arab countries for informal settlements. El-Sisi launched an ambitious program of eliminating unsafe areas and relocating their inhabitants to new housing complexes. Resettlement and upgrading decisions of ashwa'eyat are based on the Informal Settlements Development Fund (ISDF) classification of informal settlements into "unsafe" and "unplanned areas." Unsafe areas are again subdivided into two grades: grade one being "life-threatening" areas from which inhabitants must be relocated, and "grade two" areas which allow for either relocation or in-situ resettlement (Abdel-Moneim et al., 2021; Khalifa, 2011, 2015).

In the context of the relocation, different media formats are essential to the communication between the regime and the Egyptian people. Egyptian media can be categorized into the official state-owned channels (e.g., Al Ahram newspaper, official Egyptian TV channels) and privately-owned news channels, which are often under considerable government influence (e.g., Alyoum Alsabea newspaper and CBC and DMC TV channels). Since the Arab Uprisings, the successive Egyptian regimes have taken steps to limit freedom of expression and control the narrative in Egyptian media coverage (Abdulla, 2014). The "Media Ownership Monitor 2018/19" assesses the media landscape to have a "medium to high risk of (political) control over media outlets and distribution networks" and "high political control on media funding," among other factors (Reporters Without Borders, 2019).

After the 2011 uprising, alternative media with its decentralized content creation and ability to evade government control had offered a new window of opportunity to express opinions, at least for a period of time. However, the view of the Arab Uprisings as a "Facebook Revolution" is a simplified interpretation of the events and interactions between media and politics (Badr, 2019b; Richter \& Badr, 2017). Before 2011 and until 2013, newly established private media drew on blogs and social media platforms to publish on marginalized issues, helping diverse social groups to raise concerns that otherwise would not have had a public platform. Starting in 2013, however, there has been a crackdown on the internet and all alternative spaces of expression, leading to increased political leverage on the media landscape in Egypt (Abdulla, 2014; Badr, 2019a; Iskander, 2011; Richter \& Badr, 2017).

\subsection{Research Problem}

The mediatization of urban planning projects and real estate projects in Egypt has so far received little academic attention. Hendawy and Stollmann (2020) declare a "visual culture of Egypt's urbanization" but cover only a small segment of projects relevant to the affluent middle and upper classes. Wahba (2020) explored the mediatization of the Maspero triangle and how this urban development project was presented in the current sociopolitical context. A systematic analysis of governmentled mediatization for the urban development of informal settlements-especially with regards to the imageries and identities envisioned and enshrined in both official and non-mainstream media after the Arab Uprisingsis still missing. This article investigates the official narrative vs. the residents' perceptions through two case studies. Aiming at bridging the two disciplines of urban studies and media and communication studies, we explore how media plays a role in forming residents' perception and their habitats, weaving narratives that are simultaneously in- and excluding the residents themselves and show how political communication regarding those projects carries lasting embedded messages of stigmatization for the residents even after relocation.

\subsection{Methodology}

The interlinkages between urban projects, politics, and media are often overlooked in the literature on the new Arab urbanism after the Arab Uprisings. This article uses an exploratory approach, aiming to give an insight into the narratives of official media on relocation projects and to contextualize them within the broader hybrid media context and the power struggles in Egypt after the Arab Uprising, especially in recent years (2018-2021). Agreeing with other studies on authoritarian regimes and media (Badr \& Demmelhuber, 2014), the authors build on the hypothesis that professional and social media channels are utilized by different actors to produce identities and narratives centered around relocation (Richter \& Badr, 2017).

Relocation projects are discussed via two case studies in Cairo and Alexandria using qualitative analysis of different media (Table 1), participatory observation, semi-structured interviews, and the replication of statements made through Facebook (Table 2). Al-Asmarat in Cairo is the largest Egyptian relocation project with about 18,300 families as beneficiaries and resembles a gated community for the lower classes. The Alexandrian case study of Al-Max portrays the relocation of a fishing community into apartment buildings, resulting in a widespread backlash in alternative and social media for ignoring the fact that direct access to the sea is a basic need to sustain the people's livelihoods.

The discursive recount of media material produced through governmental news channels and private media outlets is contextualized with a qualitative analysis of the residents' perception of their original habitat and their new destination. For Al-Asmarat, non-probability sampling was used to select the interviewees to represent the main three places of origin and the proportion of their numbers. Furthermore, they had to be older than 16 , have spent two years in the new destination, 
Table 1. Overview of analyzed media.

\begin{tabular}{|c|c|c|c|c|c|}
\hline & Used media & $\begin{array}{l}\text { Date } \\
\text { released }\end{array}$ & Media type & $\begin{array}{l}\text { Date } \\
\text { retrieved }\end{array}$ & The identified media is used for \\
\hline \multirow[t]{6}{*}{$\begin{array}{l}\text { Professional } \\
\text { media }\end{array}$} & $\begin{array}{l}\text { Holm Gedeed } \\
\text { [New Dream] }\end{array}$ & $\begin{array}{l}30 \text { May } \\
2016\end{array}$ & $\begin{array}{l}\text { Youtube } \\
\text { documentary }\end{array}$ & July 2021 & $\begin{array}{l}\text { Analysis (mediatization and the } \\
\text { perception of relocation projects } \\
\text { "Al-Asmarat") }\end{array}$ \\
\hline & $\begin{array}{l}\text { Man Ahyaha [Who } \\
\text { Brings it to Life] }\end{array}$ & $\begin{array}{l}12 \\
\text { February } \\
2021\end{array}$ & $\begin{array}{l}\text { Youtube } \\
\text { documentary } \\
\text { (DMC channel) }\end{array}$ & July 2021 & $\begin{array}{l}\text { Analysis (stigmatization of informal } \\
\text { settlements, mediatization and the } \\
\text { perception of relocation projects } \\
\text { Al-Asmarat) }\end{array}$ \\
\hline & $\begin{array}{l}\text { Bolteya El-Ayma } \\
\text { [Swimming Bolteya] }\end{array}$ & 2008 & Movie & July 2021 & $\begin{array}{l}\text { Analysis (stigmatization of informal } \\
\text { settlements, mediatization and the } \\
\text { perception of relocation projects } \\
\text { "El-Max") }\end{array}$ \\
\hline & Elyoum & $\begin{array}{l}2016- \\
\text { present }\end{array}$ & $\begin{array}{l}\text { Online } \\
\text { newspaper }\end{array}$ & June 2019 & $\begin{array}{l}\text { Analysis (mediatization and the } \\
\text { perception of relocation projects } \\
\text { Al-Asmarat) }\end{array}$ \\
\hline & Alsharq Alawsat & 2007 & Newspaper & May 2020 & $\begin{array}{l}\text { Analysis (mediatization and the } \\
\text { perception of informal settlements } \\
\text { El-Max) }\end{array}$ \\
\hline & Tadamun & 2017 & Website & August 2021 & $\begin{array}{l}\text { Analysis (stigmatization of informal } \\
\text { settlements/mediatization and the } \\
\text { perception of relocation projects) }\end{array}$ \\
\hline \multirow[t]{5}{*}{ Social media } & $\begin{array}{l}\text { Al-Asmarat } \\
\text { tatahadth } \\
\text { [Al-Asmarat speaks] } \\
\text { (Page: } 56,594 \text { likes); }\end{array}$ & \multirow{5}{*}{$\begin{array}{l}2016- \\
\text { present }\end{array}$} & \multirow{5}{*}{$\begin{array}{l}4 \text { Facebook } \\
\text { groups/pages }\end{array}$} & August 2021 & \multirow{3}{*}{$\begin{array}{l}\text { Analysis (residents' opinions } \\
\text { about relocation projects, } \\
\text { reflections, personal } \\
\text { experiences) }\end{array}$} \\
\hline & $\begin{array}{l}\text { Al-Asmarat } \\
\text { Mubasher [Live } \\
\text { from Al-Asmarat] } \\
\text { (Page: } 28,698 \text { likes); }\end{array}$ & & & August 2021 & \\
\hline & $\begin{array}{l}\text { Al-Asmarat Today } \\
\text { [Al-Asmarat } \\
\text { Elyoum] (Group: } \\
\text { 27,600 members); }\end{array}$ & & & August 2021 & \\
\hline & $\begin{array}{l}\text { El-safha El-rasmya } \\
\text { le Hay Al-Asmarat } \\
\text { [Al-Asmarat } \\
\text { neighborhood } \\
\text { official page] (Page: } \\
6,300 \text { followers) }\end{array}$ & & & August 2021 & \multirow[t]{2}{*}{$\begin{array}{l}\text { Analysis formation (official } \\
\text { news and updates) }\end{array}$} \\
\hline & $\begin{array}{l}\text { (From a total sum of } \\
45 \text { groups) }\end{array}$ & & & August 2021 & \\
\hline
\end{tabular}

and lived in an unsafe area for more than five years. For Al-Max, relocation happened in two stages: the first in February 2018 and the second in early 2020. The selected sample for interviews covers both stages and the key user groups: housewives, children, shop owners, fish vendors, and fishermen. The number of interviews in each case was 25 , which proved a sufficient sample size to produce theoretical saturation during the limited timeframe of the study (Corbin \& Strauss, 2015).

Based on secondary resources and primary data collected in fieldwork between 2019 and 2020, a deductive qualitative analysis was conducted for each case study, using coding for the content analysis of the interviews and the text of the comments (Saldaña, 2016). The portrayal of the media material published on Facebook 
Table 2. Overview of interviews.

\begin{tabular}{lll}
\hline & Al-Asmarat & Al-Max \\
\hline Interviewed sample size & 25 & 25 \\
Timeframe of the interviews & 2019 & 2020 \\
Location & Cairo & Alexandria \\
Selection of the population sample & 1. Permanent resident in El-Asmarat for & All of them have been relocated from \\
& a minimum of two years & Al Max to the new project \\
& 2. Former permanent resident in informal & \\
& settlements for a minimum of five years & \\
& 3. Age of 16 years or older & \\
\hline
\end{tabular}

related to relocation contrasts with the residents' perception and its representation in and through social media. Unless indicated otherwise, all translations from Arabic to English are by the authors.

\subsection{Mediatization, Social Space, and the Built Environment}

To bring together the concept of mediatization and the materiality of a produced built environment, it is useful to turn to Henri Lefebvre's notion of "social space." According to Lefebvre, "(social) space is a (social) product" (Lefebvre, 1992, p. 26). In other words, the materiality of space is irrelevant outside of its realization and interpretation as a social space, but it can also not be disconnected from it (cf. Löw et al., 2008, p. 52). For analytical purposes, Lefebvre proposes three distinct components that collectively construct social space as a landscape of human interaction-spatial practice, representations of space, and representational (or lived) spaces. Spatial practices subsume the space as shaped by the dominant system of (re-)production and the everyday interaction with the physical environment. Representations of space refer to concepts of space and the imprint of power structures on our understanding of space. Representational or lived spaces, however, are the spaces as they present themselves to the subject, a physical space superimposed with meaning and symbols, a sort of creative or subversive annotation of spaces of representation (Lefebvre, 1992, pp. 33-38; Löw et al., 2008, pp. 52-53; Schmid, 2008, pp. 28, 36-38).

Both representations of space, as well as spaces of representation, offer a way to link media and the practice of mediatization of political activity with the general production of social space and the institutionalized practice of urban planning. At the very least, we should expect the phenomena described by Schulz as "amalgamation" and "accommodation" to be observable as features of mediatized urbanism (Schulz, 2004, p. 89). Amalgamation refers to media slipping into the everyday and becoming a crucial element in the perception and interpretation of our surroundings, as we document in the case study of Al-Max, where residents compose the imaginary of their home village partly based on existing film projects. This can be understood as a practice of the representational or lived space, a media imprint on the physical environment. The process of accommodation, on the other hand, refers to the non-media-based activity being streamlined in such a way that it is more readily compatible with or even subordinated under the logic of communication in relevant media. This is a process we observe in the Al-Asmarat project with its distinct emphasis on public relations.

Clearly, media has an instrumental effect on the way representations of space are produced and communicated. This is in line with Hjarvard's hypothesis on the structural impact of the logic of media on the performance of politics. According to Hjarvard, "Mediatization refers to... process, whereby social and cultural institutions and modes of interaction are changed as a consequence of the growth of the media's influence" (Hjarvard, 2008, p. 114). Due to the constant interaction of individuals and institutions with mediated content and the role of media as a coding-decoding, or interpretative device, politics and politicians are forced to shape the content of politics in accordance with what is communicable. A discursive dependency is established, shaping the public representation of institutions and their actions (Hjarvard, 2008, p. 107). Here Hjarvard picks up an argument by Mazzoleni and Schulz: As social actors and organizations accommodate themselves to the logic of media (or rather mediated communication), they become dependent on the media. He goes as far as saying that "mediatized politics is politics that has lost its autonomy" (Hjarvard, 2008, p. 107; cf. Mazzoleni, 2014; Mazzoleni \& Schulz, 1999, pp. 249-250).

Consequently, interactive social media and professional media are integrated into the policy process and how politics is performed. Hjarvard argues that media, especially modern social media with its integration of a large number of contributors and its own internal regulations, can be described as an institution of its own which has become a "structural aspect of modernity" and, as such, should be treated in research as a social-and thus by extension political-object with inherent formal and informal structures and logics of production (Hjarvard, 2008 , p. 107). The concepts of representational space and spaces of representation, as produced, conceived, 
and perceived social spaces allow us to apply this "structural" logic of mediatization to the production of social and hence mediatized spaces in our case studies areas of Al-Max and Al-Asmarat to document the central role of media in shaping communication in and about urban development projects.

\subsection{Informal Settlements and Mediatization Since the 2011 Uprising}

Even before 2011, filmmakers had turned their cameras on Egyptian slums, introducing a biased representation of the culture of these neighborhoods to public discourse. In the last two decades, informal settlements, especially in Cairo, have been framed through film production as characteristically dirty, inhabited by criminals and other immoral elements of society. Repetition has led to a stigmatized stereotype. This has been brought up in public debates questioning whether this exported stereotype of slum dwellers is morally acceptable and even reflects the actual situation in these poor areas (Elmouelhi, 2014; Mofeed \& Elgendy, 2016).

However, during the 2011 uprisings and in their aftermath, urban informality in Egypt was exacerbated, in part due to the absence of law enforcement under the status of political unrest. This resulted in a tremendous increase in informal construction. Informal settlements reached $38.6 \%$ of the total construction mass as per official statistics but are likely much higher (Central Agency for Public Mobilization and Statistics, 2016). Learning its lessons from the unrests, the Egyptian regime under the leadership of President El-Sisi has started to pay attention to the poorer citizens as a mobilizing force (Ismail, 2013). Reframing the figure of the ashwa'eyat residents as a reflection of the poverty and shortcomings of the previous regime, the government prioritized the improvement of livelihoods and the transformation of residents into proper citizens (Wahba, 2020). According to Soliman (2021), this introduced further socially and culturally stigmatizing representations of urban informality and informal residents by decision-makers and media. Unsafe areas became a problem to be overcome, and the solution offered was relocation to new housing projects (Eissa et al., 2016).

Under the slogan of "Egypt Without Slums," projects were established in several governorates. Although urban planning after the 2011 uprising has become more market-oriented, housing projects for the low-income classes are mostly carried out by the state as private sector investments in affordable housing for lowerincome groups are considered risky for developers seeking high-profit margins (Elmouelhi, 2019; Hendawy \& Stollmann, 2020; Shawkat, 2020; Sims \& Abu-Lughod, 2010). According to the ISDF's statistics, in 2014, 364 areas across Egypt were identified as unsafe (Maabady, 2015). By June 2021, celebrating seven years of President El-Sisi, short national TV advertisements documented the regime's slum relocation projects: "The Egyptians have succeeded in developing 298 ashwa'eyat unsafe areas in different governorates....177,5 thousand families have received new flats in safe and healthy areas" (Channel One, 2021). Represented as a major pillar and achievement among many other urbanization and construction projects, the reports carried an explicit message of progress and political potency.

\section{Mediatization of Urban Development Policies: Two Case Studies}

Mediatization and its interaction with politics have been widely discussed in the past decade, including influences on the content of policies, negotiation of policy, creation of public and institutional consensus, and naturally the communication about politics (Esser \& Strömbäck, 2014; Lilleker, 2006; Mazzoleni, 2014, 2014; Strömbäck, 2008). Some, like Hjarvard (2008), go as far as ascribing institutional qualities to the media, which as such perform collective functions and manage central aspects of social life via rule setting, sanctioning, and the allocation of resources. Missing in these discussions of applied mediatization is the effect of "mediatized" policies on material practices and vice versa. From the perspective of urban research-which as a discipline is concerned with the interaction of societies and the built environment - this represents an unsatisfactory flatting of the analysis of the relation between space and its social representations, as it has been debated under the term "spatial turn" (Harvey, 2016; Schroer, 2008; Soja, 1989). Implemented policies take shape in built environments of considerable durability. The interaction of residents and the wider society with these material consequences-as our case studies will showintroduces its own dynamics on mediatized imageries. While both cases are not comparable in terms of scale, they do allow for an exploratory discussion of the scope of mediatization in the discourse of ashwa'eyat and urban redevelopment projects in Egypt. In this struggle over attention and interpretation in the mediatized urban development in Egypt, three elements can be reconstructed: (a) An official representation of successful development projects through different media and tight control of this narrative, (b) a struggle by residents to participate in the public narrative on relocated settlements and voice their perception of their new environments, and (c) attempts at re-narrating qualities of place regarding the places of origin of the relocated residents.

\section{Al-Asmarat Relocation Project}

Al-Asmarat (or "Long-live Egypt City," Tahia Masr) is located in Muqattam district southeast of Cairo city. The national housing project with a total area of 78,4 ha is executed by the Egyptian government. Initiated under Cairo Governor Galal El Saeed, the relocation gathered momentum in the wake of Egypt's Vision 2030, which aimed for complete slum eradication by the end of 
2030 under the pillar of national urban development goals (I. El-Hanafi, interview, July 29, 2019; Leila, 2019). Planned in three phases with a total budget of more than three billion EGP, the project is considered a quantum leap in dealing with slums considering the scale and allocated funds (I. El-Hanafi, interview, July 29, 2019). It is to accommodate a population of over 80,000 people comprised of former residents of life-threatening areas and unsuitable shelters, mostly in Manshiyet Nasser, Istabl Antar, and Maspero (Cairo GovernorateAl-Asmarat Neighborhood Management Unit, 2019; State Information Service, 2016). The project's first and second phases were officially inaugurated by the Egyptian president on the 30th of May 2016; the third phase, in 2020. The attendance of the Egyptian president and the top statesmen has created a strong impetus for Egyptian media to pay this project special attention. For the first time in Egypt, the inauguration ceremony of a social housing project was live-streamed and broadcast on both public and private TV channels (Figure 1). In 2020, the Egyptian Prime Minister Madbouly announced the intention to replicate the model of Al-Asmarat in each governorate after the project's success to fulfill its objectives ("Egypt's Sisi directs," 2020).

\subsection{Al-Asmarat Coverage in Mainstream Media}

There were two main streams in the media coverage of the project. Firstly, in order to propagate the project as the pinnacle of the Egyptian state's achievements, the whole spectrum of public and pro-regime TV channels, official journals, filmmakers, and online content cre- ators was mobilized to capture the positive side of the project with great praise. Several documentaries were produced by the Department of Morale Affairs of the Egyptian Armed Forces and other TV channels to portray the transformation of slum dwellers' lives after their relocation to Al-Asmarat. New Dream is one of the early documentaries prepared in 2016 to portray the success of Al-Asmarat project (among other projects) in improving the lives of tens of thousands of Egyptians who were deprived of basic decent living conditions.

The project has remained in the focus of media coverage. Man Ahyaha (Who brings it to life) is the most recent documentary to portray the fruitful results of Al-Asmarat project four years after its construction, broadcast on various TV channels and online platforms. Delivered with emphatic language, it compares the residents' life before and after the relocation. Statements such as "The cries that were met by deaf ears had finally found listeners and supporters" (narrator, 00:00:16-00:00:23 hr) exemplify the governmental efforts to respond to the needs of slum dwellers. Powerful imagery is used to contrast the project with their previous undesirable habitats:

I was afraid to marry and have a kid, how would this child's future look like? He might stand at the door of the house and sell drugs, and if I reprimanded him, he might hit me or slap me in the face. (male resident, 00:02:44-00:02:50 hr)

Values such as decency and cleanliness found in the new environment are promoted through sentences such as, "The new generations will grow up in decent places and not see what we have seen or what our parents have

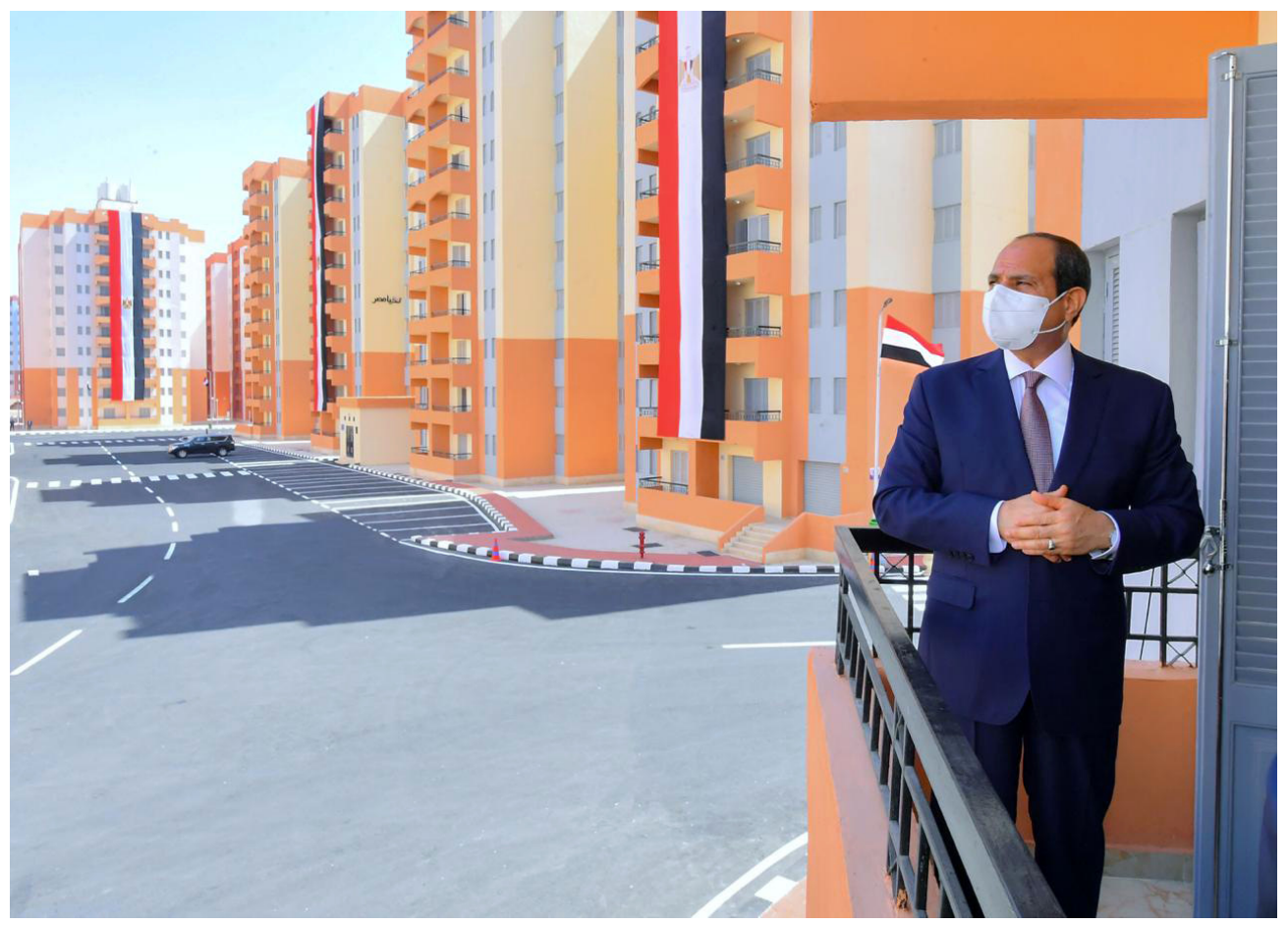

Figure 1. Media coverage for the inauguration of Al-Asmarat. Source: Sayed (2020). 
seen growing up" (young girl, 00:03:45-00:03:50 hr) and "when we came here, we found playgrounds, schools, beautiful things and good clean people" (young boy, 00:03:52-00:03:56 hr).

Some of the above-mentioned messages in Man Ahyaya and similar films have drawn the ire of relocated residents as derogatory and disrespectful of their origins and efforts to make a living. This includes designating them as former "neighbors of the dead," referring to the practice of living in large graveyards or "cities of the dead" in Cairo, and phrases such as "the nightmarish life is there no more." (narrator, 00:00:09 hr). The transformation from slum-dweller to respectable citizen and the accompanying behavioral and cultural changes are important aspects of relocation. This is affirmed by the head of the neighborhood management unit saying, "After four years, I can tell you that we have transformed the residents' behavior by $70 \%$ " ( $\mathrm{H}$. Ghandour, interview, August 4, 2019).

The image of ashwa'eyat as inhumane settlements, and Al-Asmarat as an ideal solution as effective representations of space are reinforced through these media reports. The interviewed residents suggested that the media stop humiliating the slum/ashwa'eyat dwellers and stop the stigmatization, which would encourage them to accept the relocation and improve their overall satisfaction accordingly.

To a smaller extend, opponents to the project and such interventionist policies dealing with slums are able to voice concerns through social media and online news websites. They address some of the criticisms directed at the technical, social, and economic implications. Denouncing negative reporting as "rumors," the media center of the Egyptian Cabinet has issued several statements to provide the public with supposedly correct information, as can be seen in Figure 3. They aim to counter reports of forced relocation by listing the alternatives given to residents (ExtraNews, 2020).

\subsection{Contested Representation of Al-Asmarat on Facebook}

Al-Asmarat has a strong presence on Facebook, with more than ten groups and pages dedicated to it (see Table 1). There are around 45 groups that reflect subcommunities within Al-Asmarat, such as groups for residents of certain blocks, groups based on the gender or profession of its members. These groups and pages aim to share daily news about the neighborhood and discuss problems that residents face. Only Al-safha Al-rasmya le Hay Al-Asmarat (Al-Asmarat Neighborhood official page) is created and managed by the head of Al-Asmarat neighborhood, with more than 6,000 followers. It is considered the official Facebook page for the project via which all the activities taking place in Al-Asmarat are announced.

The others are unofficial pages run by residents to discuss their daily news and internal problems. These groups usually report both positive and negative feedback allowing discussions and debates among the group members with higher tolerance to bitter criticism, unlike the official page. The Al-Asmarat Elyoum (Al-Asmarat Today) group has the highest number of members (around 25,000 members). It was accessed to collect feedback by the residents on the provided services, general impressions, and complaints.

An exploratory review of the Facebook pages reveals contradictory opinions about life in Al-Asmarat. Comments reflect the same pattern as that detected in official media. One party praises the advantages of the new life granted to the ex-slum dwellers, advocating the efforts to improve the living conditions of thousands of people. The other party uses social media as a channel to vent anger, discussing their bitter dissension and disclosing their indignation towards the project, as can be seen in Figure 4.

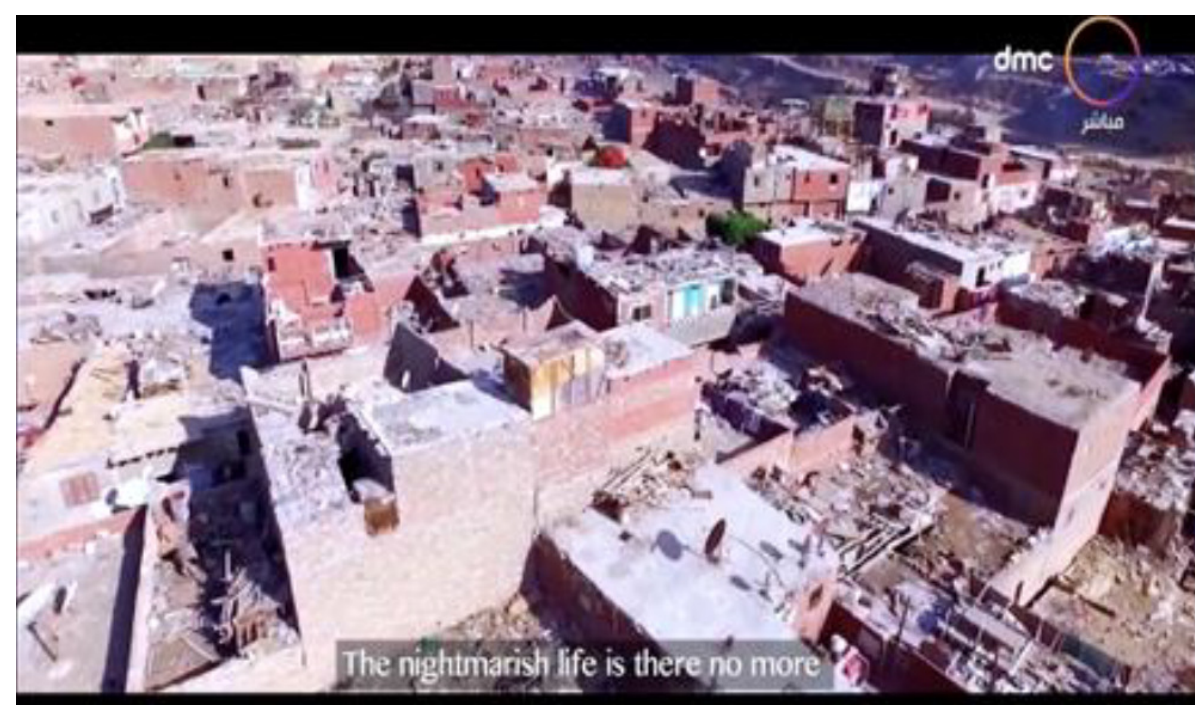

Figure 2. Still image from Man Ahyaha. 


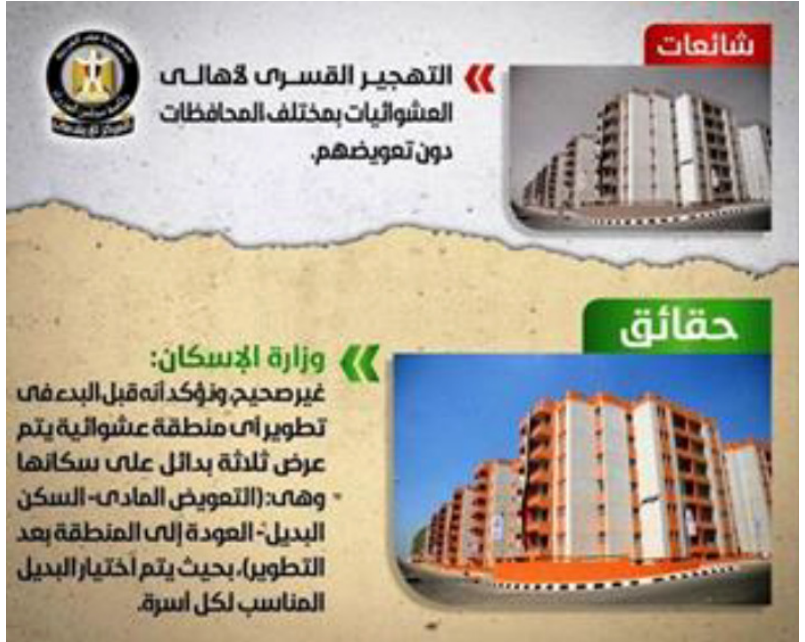

Figure 3. Official announcements to respond to rumors regarding Al-Asmarat through online channels. Note: translation"The rumor: Forced eviction for ashwa'eyat residents without compensation. Facts: Ministry of Housing: Not true, as we confirm that before developing any ashwa'eyat area, three alternatives are offered-financial compensation, alternative housing, returning to the area after development-and the appropriate alternative is chosen for each family." Source: ExtraNews (2020).
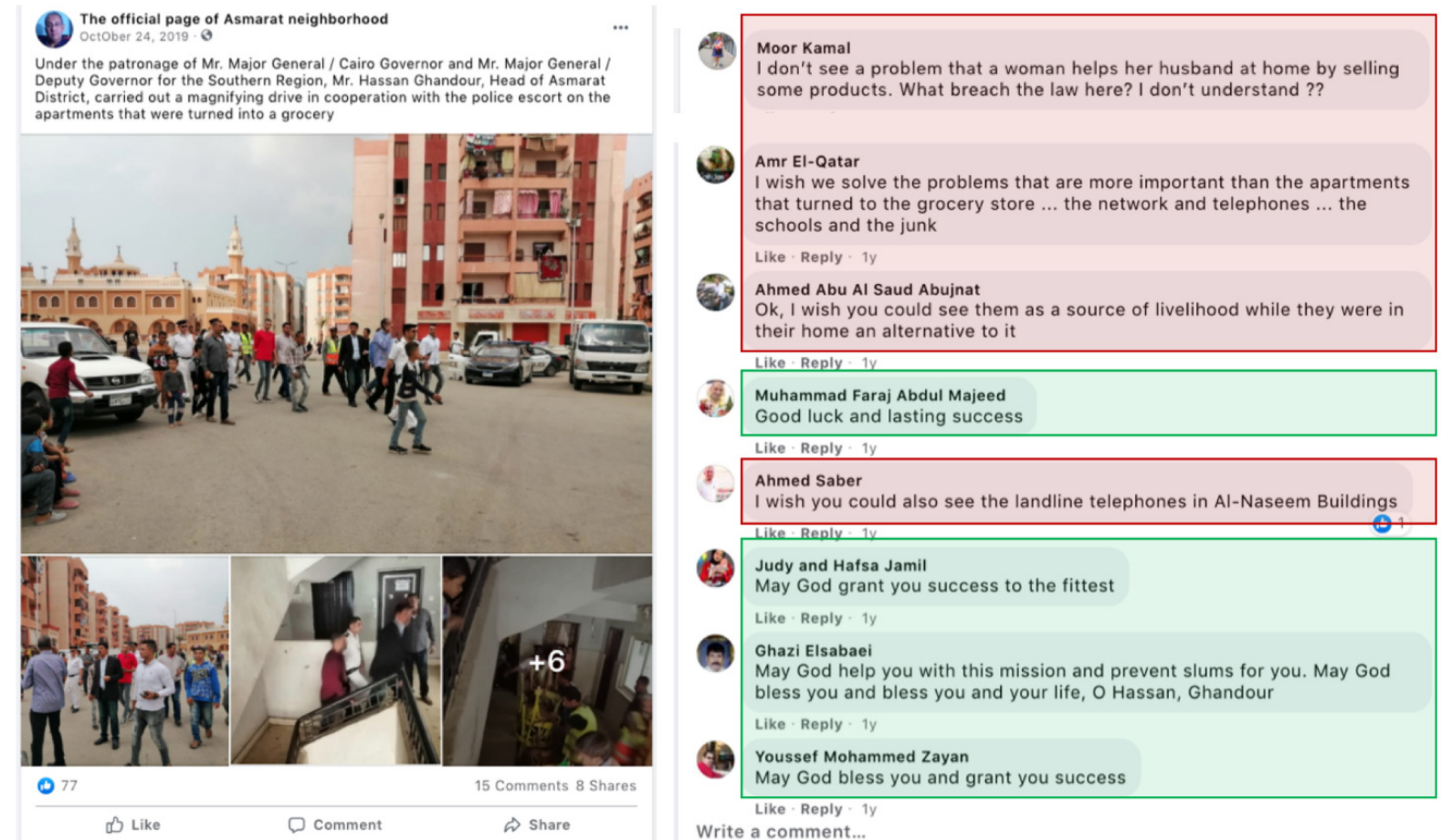

Figure 4. An example of the discussions on Facebook about the policies in Al-Asmarat. Note: Original in Arabic, translated automatically via google chrome.

\subsection{Perception of Al-Asmarat Residents}

During the fieldwork, the 25 interviewed residents expressed their annoyance regarding the representation delivered by media about slum dwellers and residents of Al-Asmarat and countered it with images of their lived, representational space. Blaming official media campaigns for sending out the wrong messages about their living conditions and ethical standards, they claim that misleading representation has resulted in the vilification of Al-Asmarat residents, with them being depicted as perpetrators of violence and crime. This representation negatively impacted the reputation of the neighborhood. Of the interviewed residents, $72 \%$ were clearly unsatisfied with media coverage and stated that they did not like to reveal their current residence to avoid being stigmatized by others if they knew they lived in Al-Asmarat. An interviewed resident said: 
"Media filmed us as uncivilized people living in shacks who were mobilized into an isolated camp [Al-Asmarat; $\mathrm{A} / \mathrm{N}$ ] as an attempt to be rehabilitated so we can be re-integrated with society afterward" (Hassan, August 6, 2019). Another resident angrily said:

Do you want me to sum it up? Here we are dealt with as criminals. They put us in a place like a jail. The only difference is that they allow us to go out daily to get our food then return again. (Ahmed, August 6, 2019)

In accordance with this information and responding to the questions during the same study, $72 \%$ of the surveyed residents showed severe to moderate dissatisfaction with the reputation of the Al-Asmarat residents. In comparison, $20 \%$ were satisfied, claiming that they currently were in a better position than their previous life in slums (residents' interviews, 2019). It is noteworthy that Eng. Ihab El Hanafi from the ISDF mentioned that there was a plan to have a fourth phase of Al-Asmarat, but the idea was declined due to the fear of tension or anger among the residents of Al-Asmarat heights compound (a high-class compound next to Long Live Egypt City). Placing what they called "a low-class compound or compound for the poor" next to them could negatively affect the image and reputation of the whole district lowering the real estate value of the apartments (I. El-Hanafi, interview, July 29, 2019). This partially contradicts the idealized representation of space prevalent in the official image of Al-Asmarat. It may also be seen as an indicator for a hyperbolic appearance of Schulz' concept of amalgamation: Egyptian resettlement policies are streamlined for media representation to such an extent that their material reality not only falls short of the image but is increasingly not a constitutive part of policymaking. The lived reality of Al-Asmarat as an inhabited space shaped by the residents has not been successfully mediatized to a wider audience and consequently has not impacted public policy until now.

\section{Al-Max Relocation Project}

The fishing village Qaryat Al-Sayadin was an approximately $500 \mathrm{~m}$ long strip of houses on the banks of the Mahmoudiya Canal between Lake Mariout and the Mediterranean Sea in Alexandria, Egypt. It is the oldest part of the Al-Max neighborhood (Hatem et al., 2019). Maps from 1917 show the early formations of the fishing village at the western border of Alexandria (Hatem et al., 2019). Most of the village inhabitants worked in fishing-related professions, inheriting their occupation generation after generation, along with lands and houses (Adel et al., 2016). The village had two to three rows of houses on each bank of the canal (Adel et al., 2016). Administratively, Al-Max Bay followed the General Authority for Fish Resources Development (GAFRD), which is under the administration of the Ministry of Agriculture and Land Reclamation. Consequently, the houses of the fishing village were owned by the GAFRD (Adel et al., 2016). The houses around the canal used to follow the property tax law, which is an indicator for partial formalization. In 2017 however, when the eviction notice was issued and the inhabitants demonstrated against it, the district's general secretary declared that the land was owned by the Ministry of Water Resources and Irrigation and that the residents were negatively impacting the canal (Mounir, 2017). In 1998, the first decree to demolish the area of the fishing village was issued (Daif, interview, July 12, 2020). This decree was annulled in 2006 when the inhabitants demonstrated against being relocated $14 \mathrm{~km}$ away from the Al-Max district (Adel et al., 2016). Daif (interview, July 12, 2020) explains that it was not a demonstration but rather an art installation as a part of the community development activities held by Gudran and joined by many community members. The fishing village in Al-Max was categorized as "grade two" in the 2009 national map of unsafe areas by the ISDF, a representation of space designating the area as "life-threatening" (Maabady, 2015; see also Khalifa, 2011, 2015). According to the strategic plans of Alexandria for the year 2032, which started to be enacted from 2010 onwards, the fishing village strip falls under the category "land owned by the Egyptian Armed Forces authority" (Nassar \& El-Sayed, 2016). After the January 2011 uprising, a cooperation agreement was signed between the ISDF and the Alexandria governorate to develop the area by building housing projects in the El-Max district and relocating sub-areas, including the fishing village. The project got the first installment of funds based on decree 73/2015 that adopted the draft of the project (Adel et al., 2016). By the end of December 2018, the east bank got a one-week evacuation notice and was evacuated in March 2019. The west bank followed by October 2019 (Baiomy, interview, June 26, 2020; Mohamed \& Amer, 2018).

\subsection{The Fishermen's Contested Narratives and Their Media Representation}

The area has drawn much attention because of its unique environment and ambiance. In 2007, the Alsharq Alawsat newspaper published an article about the fishing village and described it as the "Venice of the East." The term has been widely used ever since in many official and non-official newspapers and publications and thus forms a representational space of considerable impact (Adel et al., 2016). In 2008, the movie Bolteya El-Ayma (Swimming Bolteya) was released in cinemas in Egypt. It portrayed the then hypothetical scenario of forcibly evicting the inhabitants of the fishing village to establish a touristic project and how it would affect those families with an emotional and physical connection to the village.

Official media, mainly newspapers, reported on the project in 2017 and 2018, highlighting the importance of slum clearance and praising the efforts of the Alexandria governorate to provide housing units and eliminate 
life-threatening areas (e.g., Al Ahram, 2017). The plans were complimented for having the safety of the inhabitants as a priority and upgrading the status of the inhabitants, similar to the arguments brought forth in the official representations of the Al-Asmarat project. The visits of the governor and the ministers to the housing project were also reported (Mohammed, 2019). A few private newspapers also documented the progress of the project in terms of buildings constructed and the relocation process (e.g., Al Adawy, 2019; Al Watan, 2019). Some mentioned that the "prophecy" of the Bolteya El-Ayma is coming true (Samir \& ElZoghby, 2017).

Non-mainstream communication channels more actively represented Al-Max through workshops, reports, factsheets, websites, social media, and art projects. In January 2017, Tadamun (an online research initiative managed by the private urban development company Takween) arranged a set of workshops entitled Know Your City | Alexandria, which investigated the history and tried to assess the needs of areas studied, one of which was Al-Max. The workshop resulted in an online publication that analyzed the proposed housing solution and suggested initiating a discussion on the relocation of the fishermen to minimize harm to their jobs. The publication resulted in pressure to upgrade the services since the whole area of Al-Max lacks basic transportation, health, and education services (Hatem et al., 2019).

\subsection{Al-Max: A Romanticized Counter-Narrative?}

In 2018, the photography project Revive Memories started in the fishing village. It aimed to portray a con- nection between time, place, and people which the artist saw as the memories, the physical traces that the people can leave behind, and how they can be translated into memories (Baiomy, interview, June 26, 2020). Baiomy was able to document many of the changes to the eastern bank of the canal since the beginning of the demolition. A sequel to the project, a video installation, connected the families to their past homes and gathered their memories and stories about them. Baiomy declared that she was able to make out clear signs of grief when residents saw their demolished houses in the pictures. Some residents saw the houses, which were later destroyed, pictured for the first time since they had left and asked for copies (Baiomy, interview, June 26, 2020). A different perception of the area was spotted on Facebook: One resident of an area neighboring the fishing village commented on a post showing a picture of the old fishing village saying, "It was an unplanned and a dangerous area full of drug dealers, it's a good thing it was removed and that the people got relocated to better housing units." Someone replied that "it was false information and that the area hosted urban poor who lived and earned their living in that area before being evicted." Another comment mentioned that "they work as fishermen and depend on God, and even the best areas in the world have good and the bad" (Figure 5).

The residents' perception of media and their new home is still influenced by the recent relocation, and the interviews revealed their grief and a longing for the life they had before. Many of the relocated residents interviewed in October 2020 brought up scenes from the Bolteya El-Ayma movie repeatedly to explain how
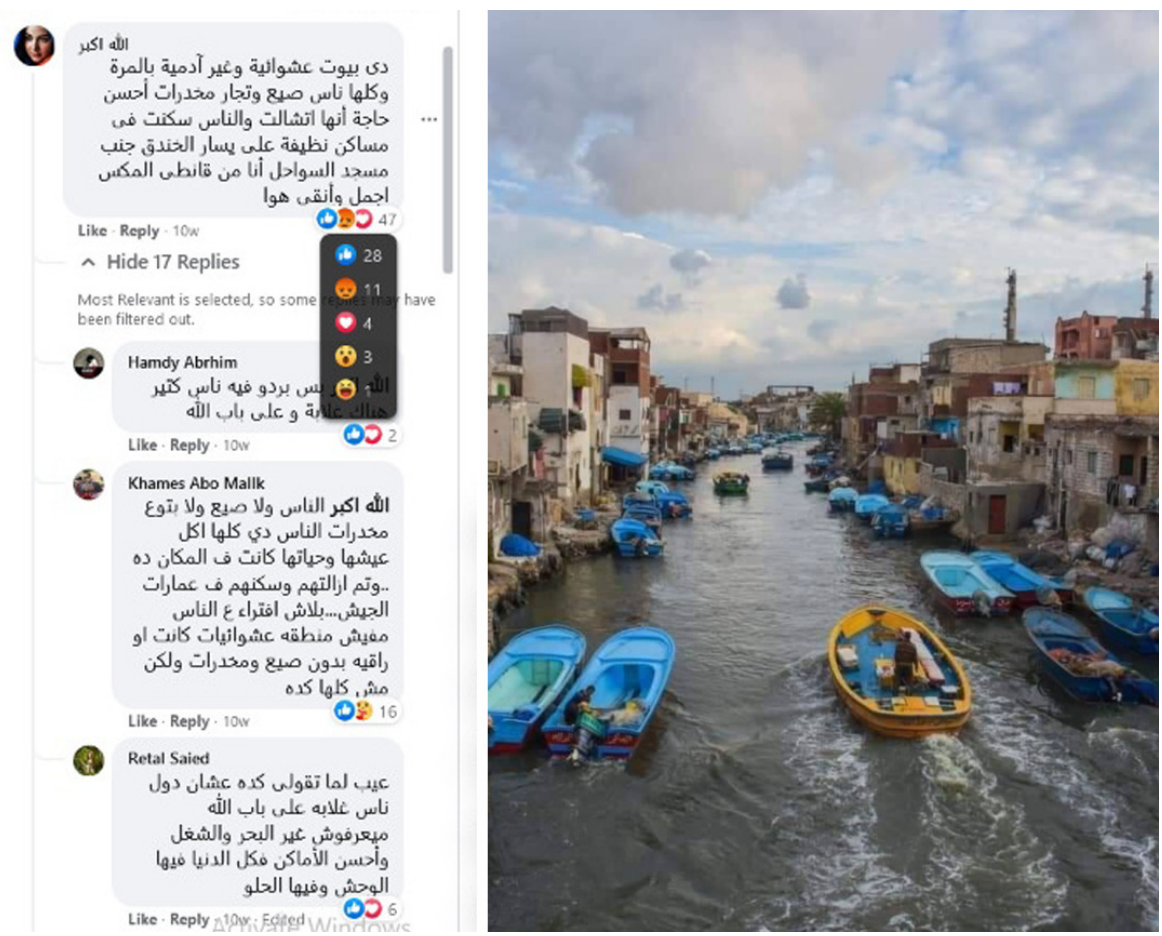

Figure 5. A screenshot for a picture of Al-Max and the comments section on a Facebook post that showed the fishing village before the relocation. 
painful it was to see their houses being demolished (see Figure 6). The representational space of the residents is clearly supplemented by the image of Al-Max as a "Venice of the East," exemplifying the process of media slipping into the everyday, which Schulz calls amalgamation (see Section 1.3).

During site visits, residents revealed that they felt neglected. They perceive that it was more important for the government to take their land because of its prime location than to care about their needs. In one interview, a fisherman screamed out that he would rather die (stating that he felt that was what the government wanted) than to feel as lost and unimportant as he did at that time. Echoing the reformatory approach to slum dwellers in Al-Asmarat, a fellow fisherman said that the government wanted to erase not only the slums but also its people because they do not fit the image the government wishes to present in the media and to the rest of the world (Fishermen, interview, October 22, 2020)

\section{Comparison and Discussion}

The two case studies are a clear depiction of the effects that mediatization has on urban development projects in Egypt. The "compound" of the Al-Asmarat housing project is presented through official media channels as a model approach for dealing with ashwa'eyat. As such, it also carries stigmatizing imageries of the plight of all informal settlements as well as the ideal type of a model home for reformed citizens, expressed as official representations of space. The media portrayal of the fully serviced relocation settlement reaffirms the official position regarding the dysfunctionality of ashwa'eyat as a place to live, work, and socialize. Past and the present are presented as polar opposites to emphasize their political achievement. However, the findings show that the stigma related to living in ashwa'eyat is sustained even after relocation, hinting at the persistence of stereotypes as well as at the failure of the mediatized narrative of the citizens' transformation to be converted on the ground.
On the other hand, Al-Max is a story of effective counternarratives through the successful placement of representational or lived spaces as opposed to official representations of space. While the destruction of the original village could not be prevented, the image of the fishermen as a community with close and necessary ties to the land (and sea) has been established through alternative media. It has become a core component of identity that is employed against the governmental narrative of progress through upgrading.

In both Al-Asmarat and Al-Max, media provides the relocated urban poor with an unfulfilled promise that improving the quality of their living environment would consequently elevate them to the level of proper citizens. The rather static idealized imagery of Al-Asmarat and Al-Max is supplemented and in part subverted by public discussions on Facebook and other social media. This study's limited scope and duration do not allow us to assess whether the discussions are fully representative of either the conditions in the new settlements or the diversity of opinions that different groups or individual residents may hold, and it does not thematize existing restrictions and risks of public expression. Nonetheless, Facebook clearly functions as a platform for debate where opinions are expressed, and perceptions shared. There appears to be room for the confrontation of official narratives through arguments and counterarguments. The efficacy of this debate in terms of influencing the mediatized discourse as well as eliciting improvements to lived reality on the ground calls for further study.

Despite the quantitative and qualitative difference between the coordinated professional media avalanche by the government and affiliated news agencies and the haphazard resistance from below through Facebook, small independent news outlets, or art projects, we observed both sides utilizing aspects of mediatization. The integration of media through the processes of accommodation and amalgamation means that the fulfillment of urban development goals is not only announced but also realized as a political achievement
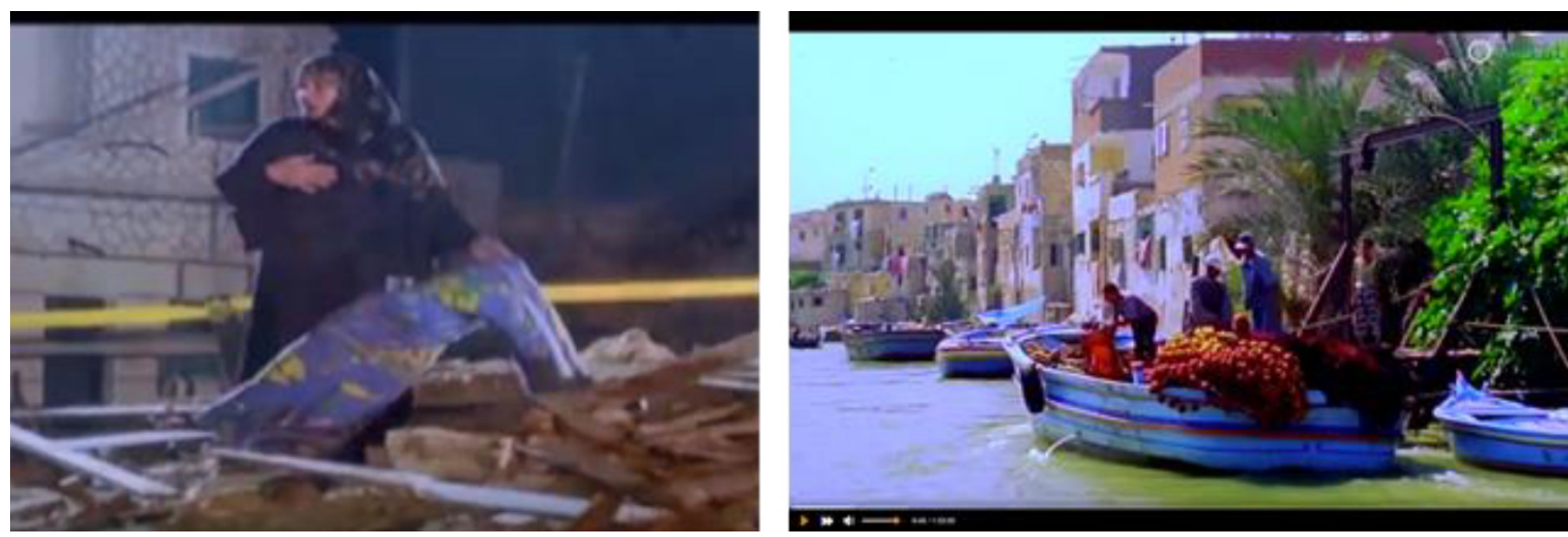

Figure 6. Still shots from Bolteya El-Ayma. Notes: On the left, the main character is standing on the ruins of her demolished house; on the right, it's a depiction of daily life using the canals. 
through its mediatization. The crime-infested informal neighborhoods, the picturesque fishermen community of Al-Max, the reformed neighborhoods of Al-Asmarat, and the new Al-Max settlement all have more bearing in their publicized and mediatized version than the lived reality on the ground, creating a mediatized replica of urban development. It remains open to discussion whether politics in Egypt has arrived at the stage of "virtualization" of interaction that Hjarvard (2008, p. 129) proposes or whether it makes empirical sense to talk about the "emancipation" of media from politics (Mazzoleni, 2014, p. 43; Strömbäck, 2008) in a state where the government effectively exerts control over large parts of mass media. Maybe the cautious warning against the risk of overemphasizing the role of media as agents of change as marked by Hepp et al. (2015) should be heeded. However, as the study of Al-Asmarat and Al-Max has shown, various forms of media play a crucial role, not only as a platform for the top-down display of urban development projects by the government and as a bottom-up forum for responses from the public, but as a strategic element for the creation of urban realities through tactical narratives by all actors involved.

This article highlights the crucial role of mediatization in configuring the socio-political and urban transformations in the societies of the post-Arab spring and opens a broader debate on modernization and state-building in the countries of the Middle East and North Africa where the interplay of media, mediatization, and urban development is tangled up with the politics of legitimacy. Beyond the described ill-effects of destroying homes and perpetuating stigmatization, powerful mediatized realities shift part of the burden of creating, maintaining, and modifying the object of political discussion to the media itself. In such contexts, the structural aspects of such institutionalized media co-opted or even co-created by authoritarian regimes can obscure accountability and the possibility of action. Bringing urban development into discussions of mediatization allows us to ask questions on the lived reality and material aspects as consequences of mediatized discourse. Further research on the mechanisms and dynamics of their interaction and possibilities of interruption is needed to understand and modulate responsible pathways for action.

\section{Conflict of Interests}

The authors declare no conflict of interest.

\section{Disclaimer}

The Arab-German Young Academy of Sciences and Humanities (AGYA) is supporting the thematic issue "Ten Years after the Arab Uprisings: Beyond Media and Liberation," edited by AGYA alumna Hanan Badr (Gulf University of Science and Technology, Kuwait) and AGYA member Lena-Maria Möller (Max Planck Institute for Comparative and International Private Law, Germany).
AGYA is funded by the German Federal Ministry of Education and Research (BMBF). The authors remain solely responsible for the content and recommendations provided in this publication, which do not reflect the positions of AGYA or any of its funding partners.

\section{References}

Abdel-Moneim, N. M., Khalil, H. A. E., \& Kamel, R. R. (2021). Developing QOL index for resettlement projects of unsafe areas in Egypt. Urban Forum, 32(3), 349-371. https://doi.org/10.1007/s12132-02109419-7

Abdulla, R. (2014). Egypt's media in the midst of revolution. Carnegie Endowment for International Peace. https://carnegieendowment.org/files/egypt_ media_revolution.pdf

Abu-Lughod, J. L. (2018). Cairo: 1001 years of the city victorious. Princeton University Press. https://doi.org/ 10.2307/j.ctv7n0cmg

Adel, N., AlGaredly, A., \& Gamal, H. (2016). fynysya alaskndryt $\mathrm{mn}$ althmysh aly althjyr [El-Mex: The Alexandrian Venice, from negligence to eviction]. Egyptian Center for Economic \& Social Rights (ECESR). https://ecesr.org/\%d8\%a7\%d9\%84\%d9\%85\%d9\%83 $\% \mathrm{~d} 8 \% \mathrm{b3}$

Al Adawy, M. (2019, June 25). Telmebat alemkes walemdekhel meshew'eat "emeraneyh qeyd alanesha" [Tolombat Al-Mex" and "AlMadkhal," urban projects under construction in Alexandria]. AlBawaba News. https://www.albawabhnews.com/ 3640788

Al Ahram. (2017, September 16). Wazer el-ray ytfaqad masaken tolobat el-max bel-eskendrya [The Minister of Irrigation inspects the housing of the Al-Max pumps in Alexandria]. Al Ahram. https://gate.ahram. org.eg/News/1583580.aspxb

Al Watan. (2019, June 15). Wazer el-eskan yatafqd mashro' tatwer mantequet tolobat al-max fe al eskandria [The Minister of Housing is checking the development of the project Tolombat El-Mex in Alexandria]. Al Watan. https://www.elwatannews.com/ news/details/4209509

Badr, H. (2019a). Transformation, social media and hybrid media systems: Rethinking counter-issues' media visibility in North Africa before and after the Arab Uprisings. In L. A. Secat, H. Gallego, \& C. Sala, (Eds.), IEMed Mediterranean yearbook 2019 (pp. 133-139). European Institute of the Mediterranean. https://www.iemed.org/publication/transformationsocial-media-and-hybrid-media-systems-rethinkingcounter-issues-media-visibility-in-north-africabefore-and-after-the-arab-uprisings

Badr, H. (2019b). Before the "Arab Spring": How challengers pushed counter-issues in Egypt's hybrid media system. Media, War \& Conflict, 14(4), 522-541. https://doi.org/10.1177/1750635219894 611 
Badr, H., \& Demmelhuber, T. (2014). Autoritäre regime, neue medien und das "regimedilemma« [Authoritarian regimes, new media and the dilemma of regimes]. Zeitschrift Für Internationale Beziehungen, 21(1), 143-160.

Cairo Governorate-Al-Asmarat Neighborhood Management Unit. (2019). Internal memorandum about El-Asmarat 'Long-Live Egypt' project. Unpublished document.

Central Agency for Public Mobilization and Statistics. (2016). The development of slums area in Egypt. https://censusinfo.capmas.gov.eg/Metadataar-v4.2/index.php/catalog/1104/download/3781

Channel One. (2021, June 24). Egyptian TV advertisement [Advertisement]. Channel One.

Corbin, J. M., \& Strauss, A. L. (2015). Basics of qualitative research: Techniques and procedures for developing grounded theory (4th edition). SAGE.

Egypt's Sisi directs to have Al-Asmarat duplicates in different governments. (2020, September 21). EgyptToday. https://www.egypttoday.com/Article/ 1/92199/Egypt's-Sisi-directs-to-have-Al-Asmaratduplicates-in-different

Eissa, D., Abd El-Moneim, N., \& Lasheen, E. (2016, November 24-25). Displacement and appropriation: Documenting the implications of inadequate resettlement policies in Cairo [Paper entry]. The Regional Studies Association Winter Conference 2016, London, UK.

Elmouelhi, H. (2014). Culture and informal urban development: The case of Cairo's Ashwa'eyat (Informal Settlements). Köster.

Elmouelhi, H. (2019). New administrative capital in Cairo: Power, urban development vs. social injustice: An Egyptian model of neoliberalism. In A. Al-Hamarneh, J. Margraff, \& N. Scharfenort (Eds.), Neoliberale Urbanisierung: Stadtentwicklungsprozesse in der arabischen Welt [Neoliberal urbanization: Urban development processes in the Arab world] (pp. 215-254). Transcript.

Esser, F., \& Strömbäck, J. (2014). Mediatization of politics: Understanding the transformation of Western democracies. http://site.ebrary.com/id/10952864

ExtraNews. (2020, December). El-hokoma tanfy egbar qateni el-ashwa'yat a'la dafa' 20 alf geneh le estelam wehdad badela [The government denies forcing slum dwellers to pay 20,000 pounds to receive alternative units]. ExtraNews. https://bit.ly/3cMRrV0

Harvey, D. (2016). Rebellische Städte: Vom Recht auf Stadt zur urbanen Revolution [Rebel Cities: From the right to the ciy to the urban revolution]. Suhrkamp.

Hatem, H., Abu Saif, J. A., \& Ali, L. (2019). Alexandria | Al-Max. Tadamun. http://www.tadamun.co/?post_ type=city\&p=10645\&amp;lang=en\&lang=en \#.YaKhLboxmUk

Hendawy, M., \& Stollmann, J. (2020). The entanglement of class, marriage and real estate: The visual culture of Egypt's urbanisation. Urban Planning, 5(2), 44-58. https://doi.org/10.17645/up.v5i2.3026

Hepp, A., Hjarvard, S., \& Lundby, K. (2015). Mediatization: Theorizing the interplay between media, culture and society. Media, Culture \& Society, 37(2), 314-324. https://doi.org/10.1177/0163443715573 835

Hjarvard, S. (2008). The mediatization of society: A theory of the media as agents of social and cultural change. Nordicom Review, 29(2), 102-131. https:// doi.org/10.1515/nor-2017-0181

Iskander, E. (2011). Connecting the national and the virtual: Can Facebook activism remain relevant after Egypt's January 25 uprising? International Journal of Communication, 5, 13-15.

Ismail, S. (2013). Urban subalterns in the Arab revolutions: Cairo and Damascus in comparative perspective. Comparative Studies in Society and History, 55(4), 865-894. https://doi.org/10.1017/S00104175 13000443

Karima, H. (2018, December 2). Egypt to be declared slum-free country by end of 2019. EgyptToday. https://www.egypttoday.com/Article/1/61300/ Egypt-to-be-declared-slum-free-country-by-end-of

Khalifa, M. A. (2011). Redefining slums in Egypt: Unplanned versus unsafe areas. Habitat International, 35(1), 40-49. https://doi.org/10.1016/ j.habitatint.2010.03.004

Khalifa, M. A. (2015). Evolution of informal settlements upgrading strategies in Egypt: From negligence to participatory development. Ain Shams Engineering Journal, 6(4), 1151-1159. https://doi.org/10.1016/j.asej. 2015.04.008

Lefebvre, H. (1992). The production of space. Blackwell.

Leila, R. (2019). Safe relocation: Egypt's plan to eradicate slums by 2030. ElAhram English. http:// english.ahram.org.eg/NewsContent/1/64/325213/ Egypt/Politics-/Safe-relocation-Egypts-plan-toeradicate-slums-by-.aspx

Lilleker, D. G. (2006). Key concepts in political communication. SAGE.

Löw, M., Steets, S., \& Stoetzer, S. (2008). Einführung in die Stadt-und Raumsoziologie [Introduction to urban and spatial sociology]. Verlag Barbara Budrich.

Maabady, B. E. (2015). Reviewing the ISDF strategy for dealing with slums in Egypt [Master's thesis, The American University Cairo]. AUC Knowledge Fountain. https://fount.aucegypt.edu/etds/1110

Mazzoleni, G. (2014). Mediatization and political populism. In F. Esser \& J. Strömbäck (Eds.), Mediatization of politics: Understanding the transformation of Western democracies (pp. 42-56). Palgrave Macmillan. https://doi.org/10.1057/9781137275844_3

Mazzoleni, G., \& Schulz, W. (1999). "Mediatization" of politics: A challenge for democracy? Political Communication, 16(3), 247-261. https://doi.org/10.1080/ 105846099198613

Mofeed, R., \& Elgendy, N. (2016). Re-presenting the Egyptian informal urbanism in films between 1994 
and 2014. International Journal of Humanities and Social Sciences, 10(6), 2044-2050. https://doi.org/ 10.5281/ZENODO.1339313

Mohamed, S., \& Amer, A. (2018, March 2). Tatwer el manateq el-ashwa'ya: Al-askndria khalia mn el-ashwa'yat be nehayt ela'm elhali [Development of Slums: Alexandria will be free of slums by the end of this year]. AlBawaba News. https://albawabhnews.com/ 2969794

Mohammed, H. (2019, June 15). Wezyer alasekan teskeyn $50 \%$ men whedat menteqh telmebat alemkes balaseknedreyh [Minister of housing: Occupying $50 \%$ of the units in the El-Max pumps area in Alexandria]. Akhbar E/Youm News. https://bit.ly/ 3FQXRz1

Mounir, J. (2017). Ahali "torombat el-max" bel askandria yaa'trdon ala el-masaken el-gdeda [Residents of "AlMax Pumps" in Alexandria object to the new housing]. Al Youm7. https://bit.ly/3COkZwa

Nassar, D. M., \& El-Sayed, M. K. (2016). Urban challenge meets hidden potentials: Sustainable development of El-Max Fishermen Village in Alexandria, Egypt. Environment-Behaviour Proceedings Journal, 1(4), 230-230. https://doi.org/10.21834/e-bpj.v1i4. 95

Reporters Without Borders. (2019). Media ownership monitor Egypt. Media Ownership Monitor. http:// egypt.mom-rsf.org/en

Richter, C., \& Badr, H. (2017). Die Entwicklung der Kommunikationsforschung und-wissenschaft in Ägypten. Transnationale Zirkulationen im Kontext von Kolonialismus und Globalisierung [The development of communication research and science in Egypt. Transnational circulation in the context of colonialism and globalisation]. In S. Averbeck-Lietz (Ed.), Kommunikationswissenschaft im internationalen Vergleich [Communication science in international comparison] (pp. 383-407). Springer. https://doi.org/10.1007/978-3-531-18950-5_15

Saldaña, J. (2016). The coding manual for qualitative researchers (3rd ed.). SAGE.

Samir, M., \& ElZoghby, A. (2017, December 7). Nobo'et "boltya el ayma" tathaqaq... a'wdet azmet ahali "vinesia el sharq" bel askandria [Bolteya El-Ayma's prophecy comes true... the crisis of the people of "the
Venice of the East" in Alexandria returns]. Al-Tahrir News. https://bit.ly/3D3F5Cx

Sayed, N. (2020, July 12). Sisi inaugurates Al-Asmarat 3 housing project in Cairo's Mokattam. Sada ElBalad English. https://see.news/sisi-inauguratesal-asmarat-3-housing-project-mokattam

Schmid, S. (2008). Henri Lefebvre's theory of the production of space: Towards a three-dimensional dialectic. In K. Goonewardena, S. Kipfer, R. Milgrom, \& S. Schmid (Eds.), Space, difference, everyday life: Reading Henri Lefebvre (pp. 27-45). Routledge.

Schroer, M. (2008). "Bringing space back in"-Zur Relevanz des Raums als soziologischer Kategorie ["Bringing space back in"-On the relevance of space as a sociological category]. In J. Döring \& T. Thielmann (Eds.), Sozialtheorie [Social theory] (2nd ed., pp. 125-148). transcript Verlag. https://doi.org/ 10.14361/9783839406830-005

Schulz, W. (2004). Reconstructing mediatization as an analytical concept. European Journal of Communication, 19(1), 87-101. https://doi.org/10.1177/ 0267323104040696

Shawkat, Y. (2020). Egypt's housing crisis. The American University in Cairo Press.

Sims, D., \& Abu-Lughod, J. L. (2010). Understanding Cairo: The logic of a city out of control (1st ed). The American University in Cairo Press.

Soja, E. W. (1989). Postmodern geographies: The reassertion of space in critical social theory. Verso.

Soliman, A. (2021). Urban informality: Experiences and urban sustainability transitions in Middle East cities. Springer.

State Information Service. (2016). Sisi inaugurates "Asmarat" low-cost housing project-SIS. https://www. sis.gov.eg/Story/101577/Sisi-inaugurates-Asmaratlow-cost-housing-project?lang=en-us\&lang=en-us

Strömbäck, J. (2008). Four phases of mediatization: An analysis of the mediatization of politics. The International Journal of Press/Politics, 13(3), 228-246. https://doi.org/10.1177/1940161208319097

Wahba, D. (2020). Urban rights and local politics in Egypt: The case of the Maspero Triangle. Arab Reform Initiative. https://www.arab-reform.net/publication/ urban-rights-and-local-politics-in-egypt-the-caseof-the-maspero-triangle

\section{About the Authors}

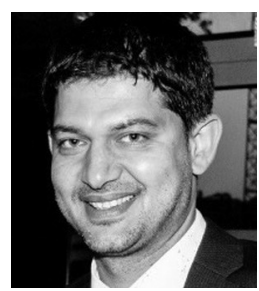

Hassan Elmouelhi (PhD) is working as a senior researcher and project leader at Campus El Gouna and the Habitat Unit at Technische Universität Berlin. His academic interests include culture and urban informality as aspects of urban development and governance in the Global South. As a researcher and consultant, he has been involved in interdisciplinary projects in Egypt, Germany, Tunisia, Tanzania, Lebanon, Iraq, Jordan, Palestine, and India, dealing with topics such as urban management, public space, refugees and migration, new settlements, land management, and localizing global agendas. 


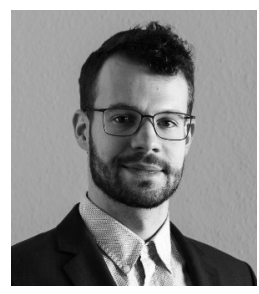

Martin Meyer has been a PhD-researcher at Technische Universität Berlin since 2017. Having worked with Violence Prevention Through Urban Upgrading in South Africa, with the GIZ in the Land Use and Settlement Program in Lesotho, and at the Building, Road, Housing \& Urban Development Research Centre in Iran, he is passionate about international urbanism and the global exchange of knowledge. In his research, he focuses on housing provision in Iran, modern heritage in the Global South, and participatory urban governance.

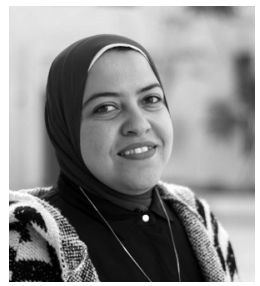

Reham Reda is an architect and urban planner with five years of experience in architecture, urban planning, urban development, and sociology. She holds an MSc in Urban Development from the Technical University of Berlin - Campus El Gouna and a BSc in Architectural Engineering from the American University in Cairo. Currently, she is working as a researcher and project coordinator at the Urban Training and Studies Institute affiliated to Housing and Building National Research Center at the Ministry of Housing in Egypt.

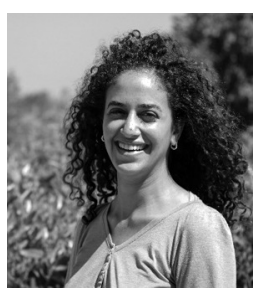

Asmaa Abdelhalim is an urban sociologist. She earned a BA in Architecture (Alexandria UniversityFaculty of Fine Arts, 2016), MA in Urban Development (Technische Universität Berlin, 2021), through a scholarship by the German Academic Exchange Service, and a scholarship from Sawiris Foundation for Sustainable Development from Egypt. She worked in community-driven development projects for start-ups in Egypt in old Cairo and South Sinai. She is mainly interested in community-based development, neighborhood management, and placemaking. 